\title{
Urinary retention and acute kidney injury in a tetraplegic patient using condom catheter after partying: a preventable complication
}

This article was published in the following Dove Press journal:

International Medical Case Reports Journal

15 October 2015

Number of times this article has been viewed

\author{
Subramanian Vaidyanathan' \\ Fahed Selmi' \\ Peter L Hughes ${ }^{2}$ \\ Gurpreet Singh ${ }^{3}$ \\ Bakul M Soni' \\ 'Regional Spinal Injuries Centre, \\ 2Department of Radiology, \\ ${ }^{3}$ Department of Urology, Southport \\ and Formby District General Hospital, \\ Town Lane, Southport, UK
}

Background: Spinal cord injury patients, who manage their bladder using a condom catheter, are at risk of developing urine retention when they consume large volumes of alcoholic drinks within a short period of time.

Case presentation: A male tetraplegic patient had been managing satisfactorily penile sheath drainage for 8 years. He went out socializing during which he consumed large volumes of alcohol but did not take any recreational drugs. The following morning, he noticed distension of the lower abdomen and passed urine in dribbles. He then developed a temperature and became unwell. He was seen by district nurses and a doctor, who prescribed antibiotics. He continued to feel unwell. After 8 days, he referred himself to a spinal unit at Regional Spinal Injuries Centre, Southport. The blood test results showed the following: blood urea: $19.8 \mathrm{mmol} / \mathrm{L}$; creatinine: $172 \mu \mathrm{mol} / \mathrm{L}$; and C-reactive protein: $336.4 \mathrm{mg} / \mathrm{L}$. Urethral catheterization led to immediate drainage of $1,400 \mathrm{~mL}$ of urine. A computed tomography scan revealed an enlarged, swollen left kidney, indicating acute bacterial nephritis. He was prescribed intravenous fluids and Meropenem. Creatinine decreased to $46 \mu \mathrm{mol} / \mathrm{L}$.

Conclusion: Spinal cord injury patients using condom catheters should be made aware of the risk of urine retention when they consume large amounts of alcoholic drinks in a short period of time. Patients and caregivers should be informed to consider intermittent catheterizations for 24-48 hours or insert indwelling urethral catheter when planning for an evening out.

Keywords: spinal cord injury, tetraplegia, neuropathic urinary bladder, acute kidney injury

\section{Background}

Condom catheter is indicated in male spinal cord injury patients with urinary incontinence provided that they have no penile lesion, and intravesical pressures during storage and voiding are urodynamically safe. ${ }^{1}$ However, detrusor function may be influenced by other factors such as consumption of large volumes of alcohol and other fluids within a short period of time. Alcohol per se may alter bladder function. Alcohol-induced bladder dysfunction has been reported, but the mechanism of its development is varied and unclear. ${ }^{2}$ We report a spinal cord injury patient using condom catheter, who developed urinary retention following a social get-together. Adequate drainage of the urinary bladder was not provided for 8 days; consequently, this patient developed sepsis and acute kidney injury.

Vaidyanathan

Regional Spinal Injuries Centre, Southport and Formby District

General Hospital, Town Lane,

Southport PR8 6PN, UK

Tel +44 I70454 747I

Email subramanian.vaidyanathan@nhs.net

\section{Case presentation}

A 21-year-old British male sustained C-5/C-6 complete tetraplegia in 1998. Since 2006, this patient had been managing his bladder by condom catheter and had no problems. 
This patient was reviewed in a spinal unit at Regional Spinal Injuries Centre, Southport in November/December 2013. He reported no difficulty in emptying his urinary bladder. An x-ray of the abdomen revealed no urinary tract calcification; urinary bladder was not distended (Figure 1A). Blood test results showed $5.4 \mathrm{mmol} / \mathrm{L}(2.3-7.5 \mathrm{mmol} / \mathrm{L})$ of urea

\section{A X-ray abdomen: $25 / 11 / 13$}

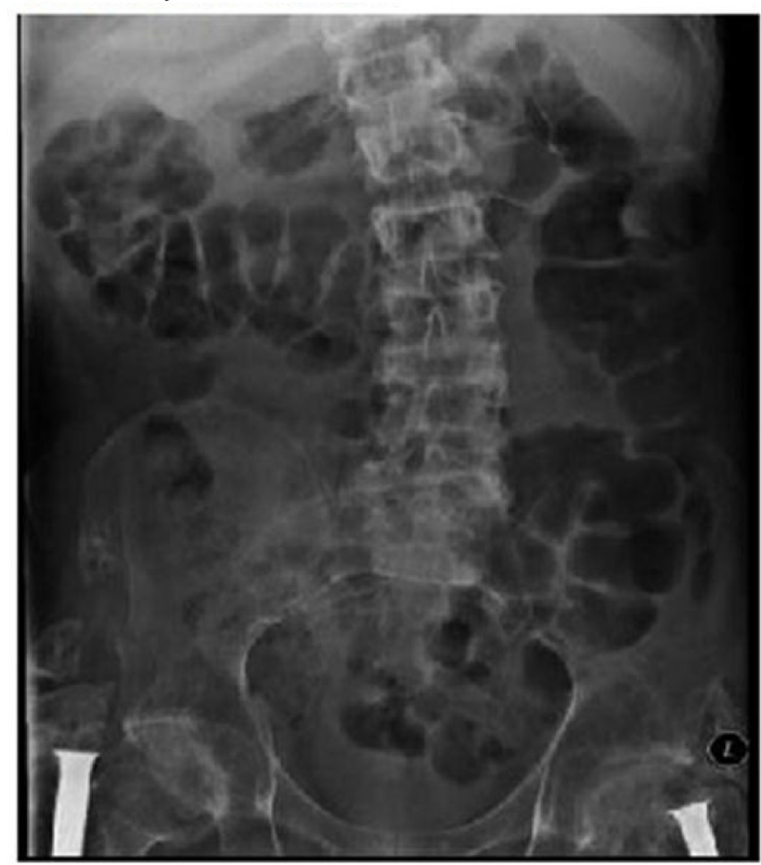

B X-ray abdomen: $17 / 11 / 14$

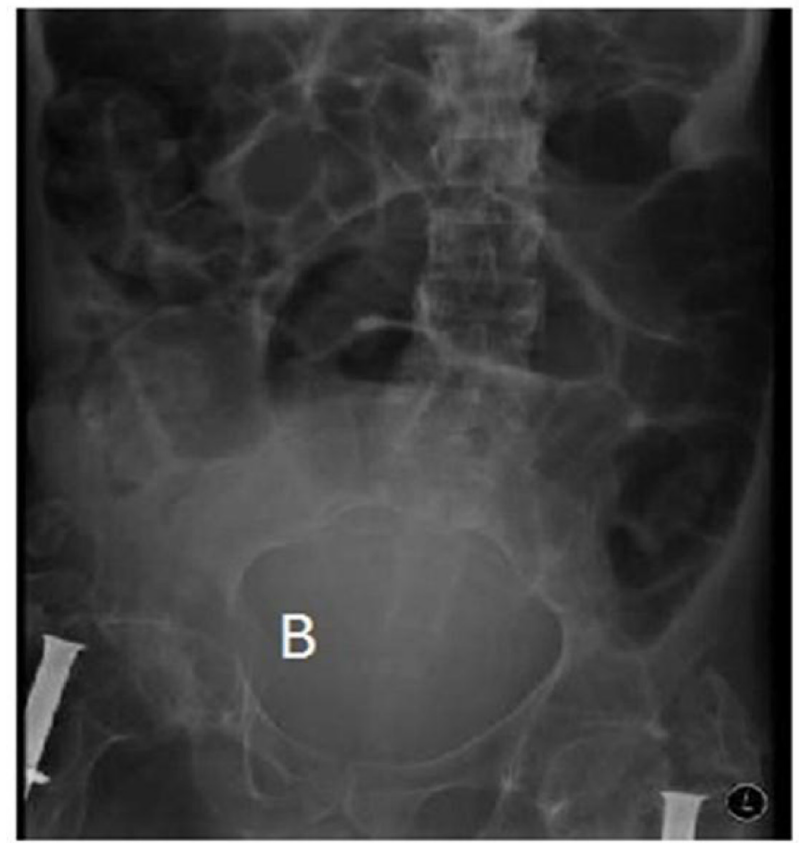

Figure I Images of urinary tract.

Notes: (A) X-ray of abdomen, taken in November 2013, revealed no urinary tract calcification; urinary bladder was not distended. (B) X-ray of abdomen, taken in November 2014, revealed large distended urinary bladder (marked as B). and $49 \mu \mathrm{mol} / \mathrm{L}(0-135 \mu \mathrm{mol} / \mathrm{L})$ of creatinine. Ultrasound examination of the urinary tract revealed normal kidneys and no hydronephrosis or calculi. The urinary bladder contained $62 \mathrm{~mL}$ of urine with moderate wall thickening (Figure 2). This patient had a well-established bowel regime and was doing all right with his neuropathic bowels and bladder.

In 2014, this patient went for an evening out with his friends and had several drinks within a short period of time. He did not take any recreational drugs during partying. Following this social get-together, he felt unwell. The next morning, he noticed swelling of the lower abdomen and passed urine in dribbles. He developed a temperature. He was seen by district nurses and a doctor, who prescribed antibiotics. This patient continued to feel unwell, and he came to the spinal unit 8 days after he went for an evening out with his friends.

On clinical examination, it was found that the urinary bladder was distended; bowel sounds were feeble; temperature: $36.4^{\circ} \mathrm{C}$; heart rate: $109 \mathrm{bpm}$; and blood pressure: 90/43 mmHg. An x-ray of abdomen revealed large distended urinary bladder (Figure 1B).

Blood tests showed the features of sepsis and acute kidney injury; urea: $19.8 \mathrm{mmol} / \mathrm{L}$ (2.3-7.5 mmol/L); creatinine: $172 \mu \mathrm{mol} / \mathrm{L}(0-135 \mu \mathrm{mol} / \mathrm{L})$; potassium: $5.7 \mathrm{mmol} / \mathrm{L}(3.5-$ $5.2 \mathrm{mmol} / \mathrm{L})$; C-reactive protein: $336.4 \mathrm{mg} / \mathrm{L}(<5.0 \mathrm{mg} / \mathrm{L})$; white cell count: $18.4 \times 10^{9}(4.0-11.0)$; and neutrophils: $162 \times 10^{9}(2.0-7.5)$. A computed tomography scan of the abdomen revealed mildly enlarged and swollen left kidney with some perinephric fluid. No calculi bilaterally and no hydronephrosis. No ureteric or bladder calculi. Urinary bladder was partially filled and trabeculated (Figure 3).

Urethral catheterization led to drainage of $1,400 \mathrm{~mL}$ of clear urine. After decompression of the urinary bladder, urethral catheter started draining blood-stained urine. This patient was prescribed Meropenem; intravenous fluids were administered.

A sample of urine, which was sent for microbiology, revealed no growth. Methicillin-resistant Staphylococcus aureus was not isolated. The sample of urine sent for cytology showed abundantly mixed inflammatory cells, some red blood cells, squamous epithelial cells, macrophages, and scattered urothelial cells in which there was focal atypia in the form of nuclear enlargement, which was probably reactive in nature.

Following drainage of the urinary bladder, blood urea decreased to $9.5 \mathrm{mmol} / \mathrm{L}$ (2.3-7.5); creatinine decreased to $62 \mu \mathrm{mol} / \mathrm{L}$ (0-135); and potassium decreased to $3.3 \mathrm{mmol} / \mathrm{L}$ (3.5-5.2). A week after instituting bladder drainage by urethral catheter, blood urea decreased further to $5.4 \mathrm{mmol} / \mathrm{L}$ (2.3-7.5); creatinine level also decreased to $46 \mu \mathrm{mol} / \mathrm{L}$ 


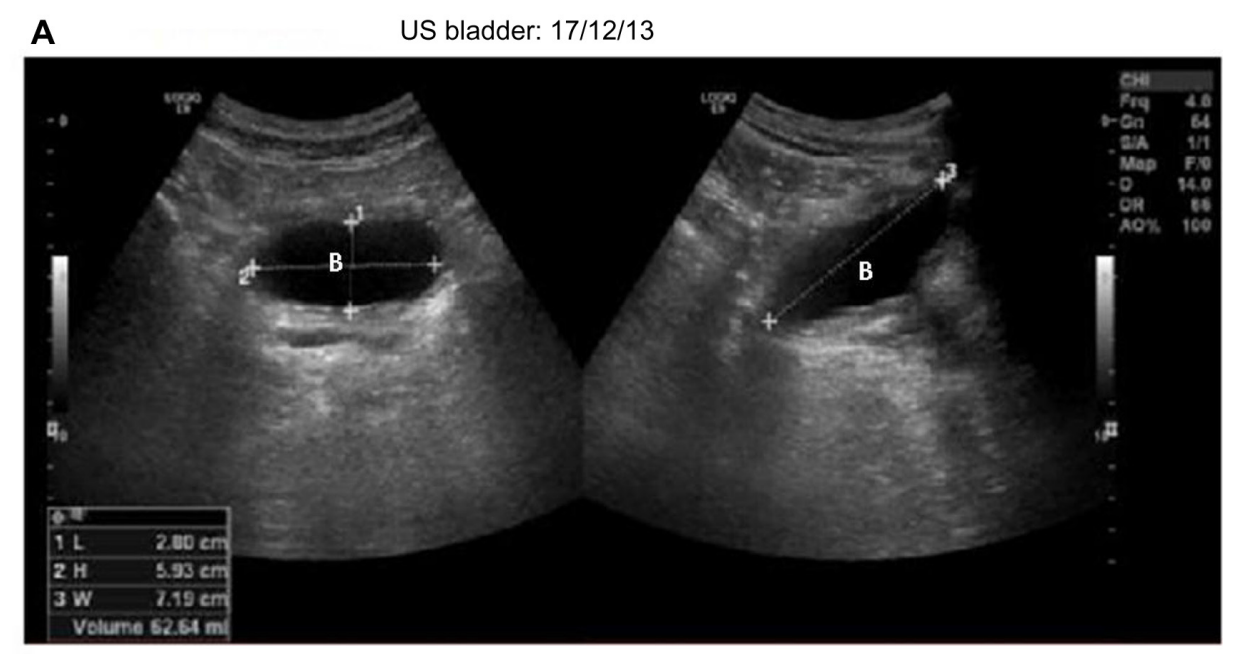

\section{B}

US bladder: 17/12/13

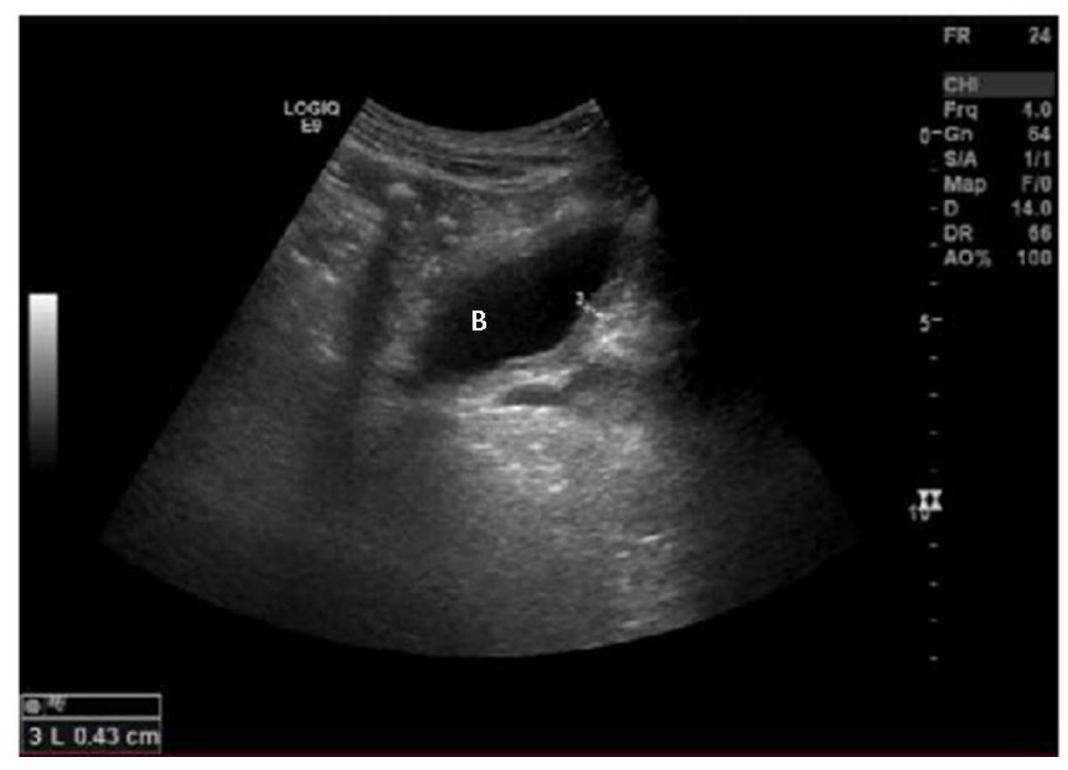

Figure 2 Images of urinary tract.

Notes: (A) Ultrasound scan, performed in December 2013, revealed no distension of urinary bladder. Bladder contained $62 \mathrm{~mL}$ of urine (marked as B). (B) Ultrasound scan of urinary bladder (marked as B), performed in December 2013, revealed moderate wall thickening, $\sim 4$ mm in diameter.

Abbreviation: US, ultrasound.

(0-135); C-reactive protein decreased to $31.4 \mathrm{mg} / \mathrm{L}(<5.0)$; and white blood cell count decreased to $9.8 \times 10^{9}(4.0-11.0)$.

Seventeen days after urethral catheterization and decompression of urinary bladder, catheter-free trial was given. But this patient could not pass urine; therefore, indwelling urethral catheter drainage was reestablished.

\section{Discussion}

Alcohol consumption increases the volume of urine held within the bladder and dulls the senses such that the patient has a reduced urge to void, despite the increased bladder volume. ${ }^{3}$ Alcohol-induced diuresis causes bladder distension and thinning of the bladder wall. Jairam et al reported a patient devel- oping spontaneous rupture of urinary bladder and oliguric renal failure after an alcohol binge. ${ }^{4}$ Our patient developed urinary retention following consumption of several drinks within a short spell of time during social get-together; subsequently, he developed a temperature and acute kidney injury; fortunately, he did not sustain a rupture of the urinary bladder. This case illustrates the need to educate male spinal cord injury patients using condom catheters, their caregivers, and health professionals the risk of urinary retention when large amounts of alcoholic drinks is taken in a short period of time. When planning for a party that involves consumption of several drinks, spinal cord injury patients using condom catheter for bladder drainage should remember that they may 


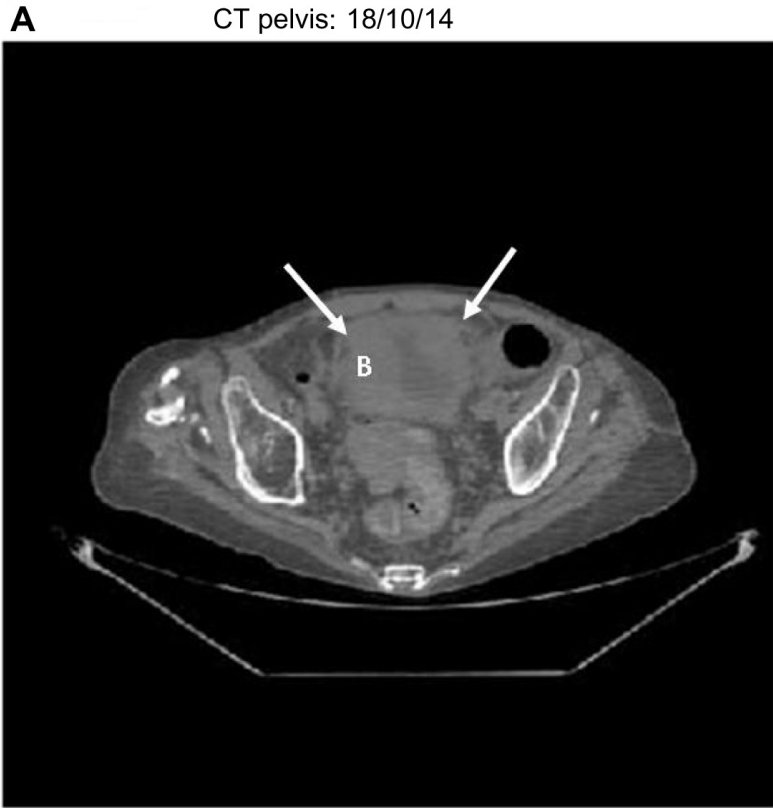

B

CT renal: $18 / 10 / 14$

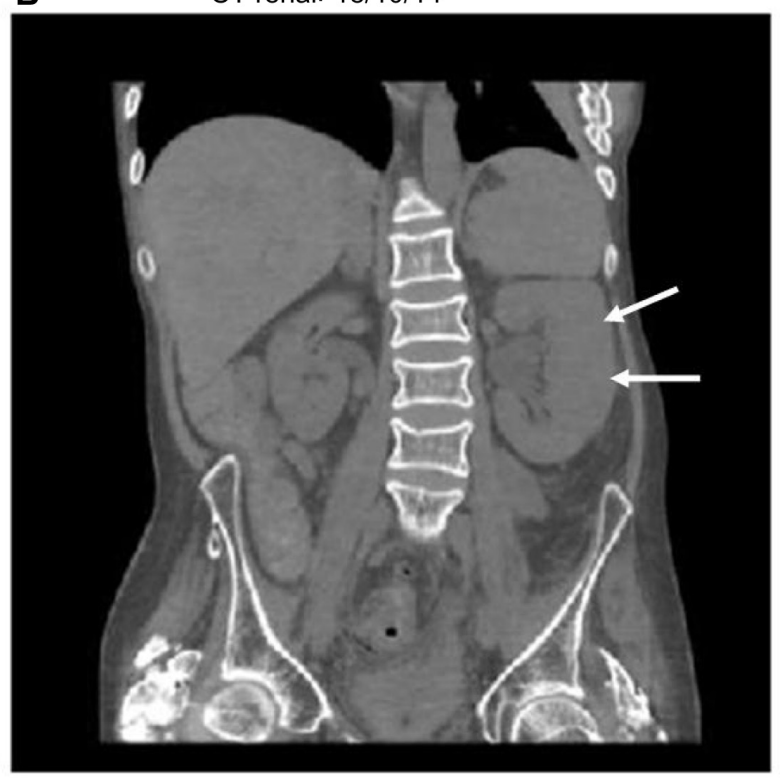

Figure 3 Images of urinary tract.

Notes: (A) Noncontrast computed tomography of abdomen and pelvis, performed in October 2014, axial section revealed thick-walled urinary bladder, which was partially filled (marked as B and also indicated by arrows). There was no fluid collection in pelvis. (B) Noncontrast computed tomography of abdomen, performed in October 2014, coronal section revealed mildly enlarged and swollen left kidney (arrows) with some perinephric fluid. No calculi bilaterally and no hydronephrosis. No ureteric or bladder calculi.

Abbreviation: CT, computed tomography.

require either intermittent catheterization for 24-48 hours or indwelling catheter. Otherwise, such patients can develop urinary retention, which in turn predisposes to urine infection, sepsis, acute kidney injury, and very rarely, rupture of urinary bladder.

\section{Conclusion}

Spinal cord injury patients who manage their urinary bladder by condom catheters run the risk of urine retention if they consume large amount of alcoholic drinks in a short spell of time. Spinal cord injury patients and carers should be made aware of this eventuality when they plan an evening out; they should consider performing intermittent catheterization for the next 24-48 hours or insert indwelling urethral catheter to ensure adequate drainage of urinary bladder.

\section{Consent}

Written informed consent was obtained from the patient for publication of this case report and any accompanying images. Ethics approval was not required for this paper.

\section{Author contributions}

SV managed the patient, conceived the idea for this manuscript, collected the data, and wrote the draft. PLH reviewed radiological images. All authors contributed toward data analysis, drafting and critically revising the paper and agree to be accountable for all aspects of the work.

\section{Disclosure}

FS and BMS were consultants in the spinal unit of Regional Spinal Injuries Centre, Southport; GS was a consultant urological surgeon at Regional Spinal Injuries Centre, Southport. The other authors report no conflicts of interest in this work.

\section{References}

1. Wyndaele JJ, Madersbacher H, Kovindha A. Conservative treatment of the neuropathic bladder in spinal cord injured patients. Spinal Cord. 2001;39:294-300.

2. Iga J, Taniguchi T, Ohmori T. Acute abdominal distension secondary to urinary retention in a patient after alcohol withdrawal. Alcohol Alcohol. 2005;40:86-87.

3. Dooldeniya MD, Khafagy R, Mashaly H, Browning AJ, Sundaram SK, Biyani CS. Lesson of the week: lower abdominal pain in women after binge drinking. BMJ. 2007;335:992-993.

4. Jairam A, Kachhela R, Mukherjee D, Hooda AK. Urinary ascites after an alcohol binge: an uncommon treatable cause of acute kidney injury. Indian J Nephrol. 2014;24:255-256. 
International Medical Case Reports Journal

Dovepress

\section{Publish your work in this journal}

The International Medical Case Reports Journal is an international, peer-reviewed open-access journal publishing original case reports from all medical specialties. Previously unpublished medical posters are also accepted relating to any area of clinical or preclinical science. Submissions should not normally exceed 2,000 words or

4 published pages including figures, diagrams and references. The manuscript management system is completely online and includes a very quick and fair peer-review system, which is all easy to use. Visit $\mathrm{http}: / / \mathrm{www}$.dovepress.com/testimonials.php to read real quotes from published authors.

Submit your manuscript here: http://www.dovepress.com/international-medical-case-reports-journal-journal 